\title{
Fluid Flow and Sub-Bactericidal Release of Silver from Organic Nanocomposite Coatings Enhance ica Operon Expression in Staphylococcus epidermidis
}

\author{
Maria G. Katsikogianni ${ }^{1,2}$, Antigoni Foka ${ }^{3}$, Eloisa Sardella ${ }^{4}$, Chiara Ingrosso ${ }^{5}$, Pietro Favia ${ }^{4}$, \\ Annarosa Mangone ${ }^{4}$, Iris Spiliopoulou ${ }^{3}$, Yannis F. Missirlis ${ }^{1^{*}}$ \\ ${ }^{1}$ Laboratory of Biomechanics and Biomedical Engineering, Department of Mechanical Engineering University of Patras, Rion, \\ Greece; ${ }^{2}$ Biomaterials and Tissue Engineering Research Group, School of Dentistry, University of Leeds, Leeds, UK; ${ }^{3}$ Department of \\ Microbiology, School of Medicine, University of Patras, Rion, Greece; ${ }^{4}$ Institute of Inorganic Methodologies and Plasma (IMIP) \\ CNR, Bari, Italy; ${ }^{5}$ CNR-IPCF Sez, Bari c/o Dipartimento di Chimica, Università di Bari, Bari, Italy. \\ Email: ${ }^{*}$ yfmissirlis@gmail.com
}

Received November $13^{\text {th }}, 2013$; revised December $13^{\text {th }}, 2013$; accepted December $23^{\text {rd }}, 2013$

Copyright (C) 2013 Maria G. Katsikogianni et al. This is an open access article distributed under the Creative Commons Attribution License, which permits unrestricted use, distribution, and reproduction in any medium, provided the original work is properly cited. In accordance of the Creative Commons Attribution License all Copyrights (C) 2013 are reserved for SCIRP and the owner of the intellectual property Maria G. Katsikogianni et al. All Copyright (C) 2013 are guarded by law and by SCIRP as a guardian.

\begin{abstract}
The present study investigates the effect of a silver (Ag)-containing nanocomposite coating on Staphylococcus epidermidis adhesion and icaA gene expression. Bacterial interactions with organic coatings with and without Ag nanoclusters were assessed through a combination of both conventional phenotypic analysis, using microscopy, and genotypic analysis, using the relative reverse transcription Real-Time Polymerase Chain Reaction (RT-PCR). The results suggest that the incorporation of $\mathrm{Ag}$ in organic coatings can significantly decrease bacterial adhesion and viability with time, in comparison to the organic coating alone. The initial Ag release though at concentrations lower than the bactericidal, significantly increased $i c a A$ gene expression for the bacteria interacting with the Ag containing coating two hours post adhesion, especially under the higher shear rate. Stress-inducing conditions such as sub-bactericidal concentrations of $\mathrm{Ag}$ and high shear rate can therefore increase icaA expression, indicating that analysis of gene expression can not only refine our knowledge of bacterial-material interactions, but also yield novel biomarkers for potential use in assessing biomaterials antimicrobial performance.
\end{abstract}

Keywords: Bacterial Adhesion; Silver; Nanocomposite; Plasma Polymerisation; Gene Expression; Shear

\section{Introduction}

Along with the implantation of artificial organs and medical devices, the use of synthetic materials has become an indispensable part in almost all fields in medicine. Poly (ethylene terepthalate) (PET) is used in certain medical implants such as artificial heart valve sewing rings and artificial blood vessels due to its good mechanical properties and relatively high biocompatibility [1]. However, as is the case of most biomaterials, its long-term use is impeded by infections $[2,3]$. While a variety of microorganisms are involved in medical device-associated infections, coagulase-negative staphylococci, specifically Sta-

\footnotetext{
${ }^{*}$ Corresponding author.
}

phylococcus epidermidis, has been identified as a predominant cause of infection in the presence of a medical device [4], due to its ability to adhere to surfaces, followed by the production of slime, and the formation of biofilm $[5,6]$. In the case of S. epidermidis the accumulative phase of biofilm formation mainly depends on polysaccharide intercellular adhesin (PIA) synthesis that is encoded by the icaADBC operon $[7,8]$.

Recent publications have outlined the necessity to develop a strategy to reduce bacterial adhesion to aortic grafts $[9,10]$. The main goals of management are the removal of the infected graft material and the re-establishment of vascular continuity [9,11]. However, these procedures are associated with a high mortality and 
re-infection rate. Moreover, conservative management comprising long-term intravenous antibiotics has been reported [12]. Although the loading of materials with antibiotics seems to be an effective method to reduce biofilm formation, the ongoing release of antibiotics promotes the development of resistant strains and the risks for the spread of such resistance, following the biomaterial prophylactic and therapeutic clinical use [13].

An alternative to antibiotics for reducing bacterial viability and adhesion on medical devices is to focus on materials that release antimicrobial agents such as Ag [14]. It has been suggested that impregnation of Ag into a coating can be more effective than direct surface coating alone, since surface Ag can be readily deactivated by protein anions, while Ag release cannot be controlled in the case of Ag coatings [15,16]. Polymers that release Ag in the oxidised form have shown strong antibacterial activity and would act as reservoirs of $\mathrm{Ag}$ and be capable of releasing Ag for extended periods [17].

In this direction the present study investigated the effectiveness of Ag-containing organic coatings (Ag: $\mathrm{CxHyOz)}$ plasma-deposited on polyethylene terephthalate (PET), which contains oxygen functionalities that can be involved in the mechanism of Ag release, against initialbacterial adhesion and biofilm formation and how this is related to icaA gene expression.

Assessment of icaA DBC operon genes' expression has become crucial to the understanding of the pathogenesis of $S$. epidermidis infections $[18,19]$, and reverse transcription (RT) followed by polymerase chain reaction (RT-PCR) represents a powerful tool for gene expression studies through the detection and quantification of mRNA. Quantification is realized by the relative RTPCR by the determination of the expression level of the target gene versus a housekeeping gene [20]. The icaA gene product is a transmembrane protein with homology to N-acetyl-glucosaminyltransferase [21]. The icaA gene was therefore selected to be tested as marker of ica operon activity, because it encodes the first component of biofilm formation.

Although there is evidence that Ag interferes with the bacteria-bacteria interactions [22], according to our knowledge, there is no publication so far relating the effect of $\mathrm{Ag}$ on $i c a A$ expression.

Moreover, since the process of bacterial adhesion to indwelling medical devices is associated in most cases with flow of body fluids [23], in this work bacterial adhesion to the various substrates was examined under two shear rates 50 and $2000 \mathrm{~s}^{-1}$, which corresponded to the physiological shear rates for stable laminar flow in blood vessels, and the effect of shear rate on icaA expression was investigated as well.

\section{Materials and Methods}

\section{1. $\mathrm{CxHyOz}$ and $\mathrm{Ag}: \mathrm{CxHyOz}$ Coatings Deposition}

Organic coatings containing Ag were deposited on PET substrates through a combined strategy in which a plasma enhanced chemical vapour deposition process is simultaneous with a sputtering ones. A flow of Diethylene glycol dimethyl ether vapours of $0.25 \mathrm{sccm}$ mixed with $20 \mathrm{sccm}$ of argon was used as gas feed. An asymmetrical, parallel plate plasma reactor described in detail elsewhere was used for the plasma depositions [14]. Briefly, the reactor is equipped with a $7 \mathrm{~cm}$ dia. RF electrode and a ground one of $18 \mathrm{~cm}$ separated each other by a gap of $6 \mathrm{~cm}$. Due to the smaller area of the cathode, under proper experimental conditions (high RF power, low pressure, low DEGDME/Ar flow ratio), a bias-induced ion bombardment results at this electrode, which prevents the deposition of any coating, and induces the sputtering of silver atoms, as evidenced by Optical Emission Spectroscopy [24,25]. Substrates were positioned at the large, ground electrode. The chemical composition of $\mathrm{Ag}$ :CxHyOz films (C/O/H composition, Ag-content), as well as the dimensions of the Ag clusters can be tuned by adjusting the deposition parameters. A pressure of 50 mTorr and a power of $60 \mathrm{~W}$ were used for the plasma depositions.

In order to investigate if the nanocomposite containing coating Ag or the organic one is responsible for the antibacterial character of the material, plasma deposition of the organic coating was realized under the same experimental conditions by replacing the silver target with a stainless steel one.

\subsection{Physicochemical Characterization of the Coatings}

The plasma deposited coatings were analyzed by means of physicochemical characterizations performed using X-ray Photoelectron Spectroscopy (XPS), Water Contact Angle (WCA) measurements, Atomic Force Microscopy (AFM) and Ag release measurements. The aim of such analysis was to assess if the chemical composition of the organic matrix (i.e. $\mathrm{CxHyOz}$ ) was the same with or without the presence of $\mathrm{Ag}$ embedded in the coating, to assess if the chemical/morphological changes derived from the inclusion of $\mathrm{Ag}$ in the coating can dramatically affect the wettability of the analyzed samples, to investigate if there was any change in the surface morphology that can be attributed to the presence of Ag clusters included in the organic layer during plasma process and to evaluate the amount of $\mathrm{Ag}$ that was released from the substrate within the first $24 \mathrm{~h}$. 


\subsubsection{X-Ray Photoelectron Spectroscopy}

(XPS) measurements were performed with a Theta Probe Thermo VG Scientific instrument (base pressure $1 \times 10^{-9}$ mbar) equipped with a monochromatic $\mathrm{AlK} \alpha$ radiation (hv: $1486.6 \mathrm{eV}$ ) operating at $300 \mathrm{~W}$ with a spot size of $400 \mu \mathrm{m}$. The analysis was carried out by an angle resolved mode acquiring simultaneously information from different take-off angles (T.O.A.s) ranging from $59.5^{\circ}$ to $14.5^{\circ}$ with a conical angle of acceptance of $33^{\circ}$, by using a two-dimensional detector that collects signal intensities in both photoelectron energy and photoemission angle. The two-dimensional detector was placed at the output plane which has the photoelectron energy dispersed in one direction and the angular distribution dispersed in the other direction. Samples were neutralized for the electrostatic charging by means of a flood gun (Mod. 822-06 FG) operating at $400 \mu \mathrm{A}$ emission current, $40 \mathrm{~V}$ extraction voltage at $2 \times 10^{-7}$ mbar to correct differential or non-uniform charging. The high resolution spectra were shifted to their correct position by taking C1s spectrum centred at $285.0 \mathrm{eV}$ as reference [26].

\subsubsection{Water Contact Angle Measurements}

A Ramè-Hart-NRL mod. 100 was used to measure dynamic water contact angle (WCA) values with double distilled water. Advancing WCA $\left(\theta_{\text {adv }}\right)$ was measured by increasing the volume of the water drop in $2 \mu \mathrm{l}$ steps, until the WCA remained constant. Receding WCA $\left(\theta_{\text {rec }}\right)$ was measured by decreasing the volume of the drop until the WCA value remained constant and the solid/liquid interface started to decrease. Five samples from each group were utilized for WCA measurements. For each sample, five readings of $\theta_{\mathrm{adv}}$ and $\theta_{\mathrm{rec}}$ were measured at different regions and averaged.

\subsubsection{Atomic Force Microscopy (AFM)}

Topographic AFM images were collected in tapping mode by using a PSIA XE-100 SPM System operating in air and at room temperature. A high frequency silicon cantilever for non-contact/tapping mode purchased from NanoWorld was used. A silicon SPM sensor for noncontact AFM (Park Systems) having a spring constant of $42 \mathrm{~N} \cdot \mathrm{m}^{-1}$ and a resonance frequency of $330 \mathrm{kHz}$ was used. Micrographs were collected on six areas of each sample, with a scan size area of $5 \times 5 \mu^{2}$, by sampling the surface at a scan rate within $1.0-0.5 \mathrm{~Hz}$ and a resolution of $256 \times 256$ pixels. Topography AFM images were processed by using the XEI software to obtain statistical data of the surface root-mean-squared (RMS) roughness values of the films and mean heights of sample features.

\subsubsection{Silver Release}

The amount of Ag release was evaluated by Inductively
Coupled Plasma Mass Spectrometry (ICP-MS) analysis which was performed by means of aTJA-IRIS-Advantage spectrometer (laboratory CHIMIE s.r.l. Triggiano, Bari) with echelle optics and Charge Injection Device (CID) semiconductor detector, axial and radial viewing and a wavelength range $170-900 \mathrm{~nm}$. Plasma coated samples were soaked in $50 \mathrm{ml}$ of double distilled water at $37^{\circ} \mathrm{C}$ for 24 hours and the liquid was analyzed by the ICP-MS.

\subsection{Bacterial Culture Conditions}

The bacterial strain used in this study was the ica-positive slime producing reference $S$. epidermidis ATCC 35984. Bacteria that were in the mid-exponential growth phase, after growth in Brain-Heart Infusion Broth (BHIB, Difco Laboratories, Detroit, USA), were harvested and resuspended in $0.9 \% \mathrm{NaCl}$ at a concentration of $3 \times 10^{9}$ Colony Forming Units (CFUs)/ml [27].

\subsection{Dynamic Bacterial Adhesion Assays}

To evaluate the bacterial adhesion under flow conditions and investigate the combined effect of flow and surface chemistry on ica gene expression, the parallel plate flow chamber (PPFC) described by Stavridi et al. [28], was used. The pump was programmed to travel the pistons back and forth every $60 \mathrm{~s}$. The shear rate (S) was calculated by the following formula:

$$
S=\frac{6 Q}{W h^{2}}
$$

where $Q$ is the flow rate, $W$ (width of the chamber) $=$ $0.015 \mathrm{~m}$ and $h$ (height of the chamber) $=0.35 \times 10^{-3} \mathrm{~m}$.

All experiments were carried out at $37^{\circ} \mathrm{C}$ by placing the experimental setup inside a thermostated box (INFORS HT, Bottmingen, Switzerland), as described by Foka et al., [27]. Two shear rates were used: 50 and 2000 $\mathrm{s}^{-1}$ and bacterial adhesion and gene expression were examined two hours post adhesion.

\subsection{Examination and Quantification of Bacterial Adhesion and Biofilm Formation}

\subsubsection{Colony Forming Units Counting Method}

After the adhesion experiments, adherent bacteria were detached by immersing each sample in trypsin (SigmaAldrich) at $37^{\circ} \mathrm{C}$ for $5 \mathrm{~min}$ and using a cell scrapper (Sigma-Aldrich). Trypsin was inactivated with Fetal Bovine Serum (FBS, Sigma-Aldrich). Then 10-fold serial dilutions of the detached adherent bacteria were inoculated onto Trypticase Soy Agar (TSA, Difco Laboratories, Detroit, USA) plates, and the numbers of adherent bacterial colonies were counted after $18 \mathrm{~h}$ of incubation at $37^{\circ} \mathrm{C}$. 


\subsubsection{Scanning Electron Microscopy}

In order to be examined with Scanning Electron Microscope (SEM)(JEOL-JSM 6300, Hertfordshire, UK), each sample was fixed, dehydrated and sputter coated with gold. Images were processed using the Image Pro Plus Analysis Software (Media Cybernetics), in order to quantify the percentage of surface area covered by bacteria.

\subsection{3. icaA Gene Expression Study}

After the adhesion experiments, adherent bacteria were detached by trypsin (Sigma-Aldrich) and collected by centrifugation, as described by Foka et al., [27]. The bacterial pellets, kept at $-20^{\circ} \mathrm{C}$, were used for RNA isolation, within a week after collection using the Trizol method (Invitrogen, Carlsbad, USA), while the samples were examined in sets of four so that their processing was well controlled and consistent [27]. Genomic DNA contamination was tested by PCR with specific primers, using the appropriate reaction mix composition and thermal conditions for icaA gene [29] and a 207 bp part of the region $\mathrm{V}$ in the 23S rDNA gene [27]. Complementary DNA (cDNA) synthesis was carried out using $0.5 \mathrm{ng}$ total RNA, 50 ng random hexamers primers and the SuperScript First-Strand Synthesis System for RT-PCR (Invitrogen).

Real Time PCR for icaA gene and the 207 bp part of the region $\mathrm{V}$ in the 23S rDNA gene were carried out with the RotorGene device (RG-3000, Corbett Research, Sydney, Australia). The same primers used for the conventional PCRs were applied [27,30]. Each run included one ica-negative and a non template control as negative controls. The specificity of the PCR products was confirmed by analysis of the dissociation curve. The results were evaluated using the Rotor-Gene Analysis Software
6.0. The efficiency of reactions was calculated from the slope according to the equation $\mathrm{E}=10^{-1 / \text { slope }}$ [20].

Relative RT-PCR constituted the rate of the expression levels of icaA comparing the absolute values towards those of the reference gene (23S rDNA) [27,31].

\section{Statistical Analysis}

The effects of the surface chemistry and flow conditions on bacterial adhesion, biofilm formation, and icaA geneexpression were statistically analyzed using the SPSS package for windows. One way analysis of variance (ANOVA) was performed using the Scheffe significant difference test. Moreover, regression analysis and correlation coefficients $\left(R^{2}\right)$ were obtained using SPSS. Correlations were taken as significant for $\mathrm{p}<0.01$.

\section{Results}

\subsection{X-Ray Photoelectron Spectroscopy}

Figure 1 shows the low resolution XPS spectra acquired on $\mathrm{CxHyOz}$ coatings deposited in the same experimental conditions but with (i.e. $\mathrm{Ag}: \mathrm{CxHyOz}$ ) or without (i.e. $\mathrm{CxHyOz}$ ) the presence of $\mathrm{Ag}$ embedded inside the organic matrix. When a stainless steel target was used instead of an $\mathrm{Ag}$ one a presence of a coating containing no other elements than carbon and oxygen is deposited as confirmed by the XPS spectrum acquired on $\mathrm{CxHyOz}$ sample (Figure 1). By replacing the stainless steel target with a $\mathrm{Ag}$ one, a coating containing $\mathrm{Ag}$ was obtained as shown by the presence of the characteristic Ag3d, Ag3p, $\mathrm{Ag} 4 \mathrm{p}, \mathrm{Ag} 4 \mathrm{~s}$ and $\mathrm{Ag} 4 \mathrm{~d}$ peaks in the low resolution spectrum (see Ag:CxHyOz spectrum in Figure 1).

The best fitting of the XPS C1s spectrum acquired on $\mathrm{Ag}: \mathrm{CxHyOz}$ coatings (Figure 2(a)) shows the presence

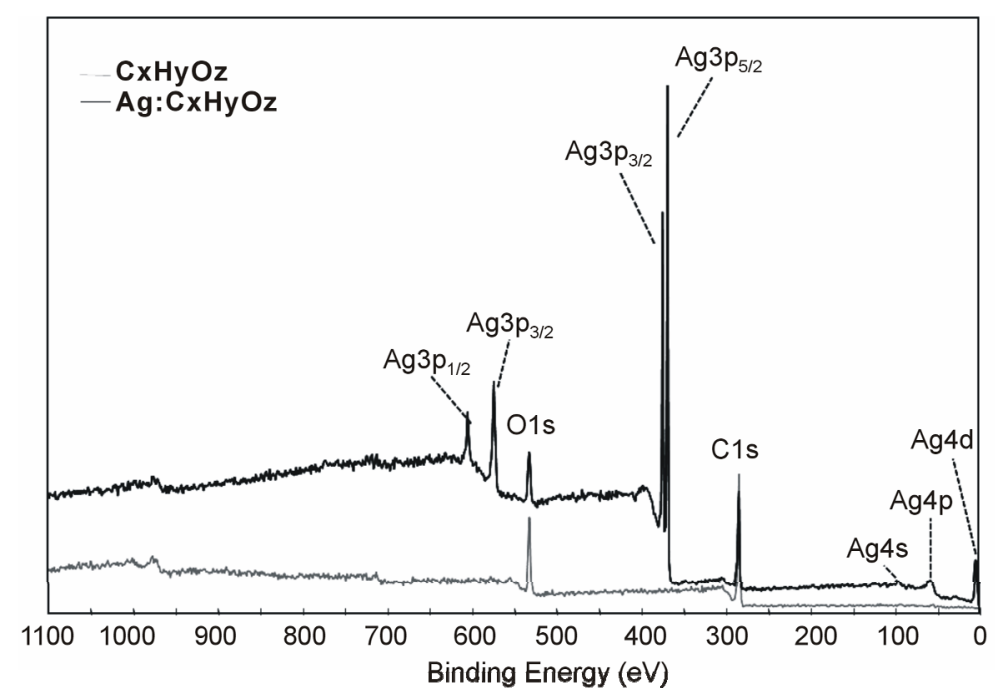

Figure 1. Low resolution XPS spectra acquired on $\mathrm{CxHyOz}$ and $\mathrm{Ag}: \mathrm{CxHyOz}$ samples. 
of different oxygen containing functionalities. The percentage of hydroxyl/ether groups attesting for the retention of the chemical structure of the precursor (i.e. DEGDME) in the coating was very low. Table 1 presents the elemental percentages of $\mathrm{C}, \mathrm{O}$ and $\mathrm{Ag}$ of the $\mathrm{CxHyOz}$ and $\mathrm{Ag}: \mathrm{CxHyOz}$ coatings. The $\mathrm{CxHyOz}$ coatings presented an $\mathrm{O} / \mathrm{C}$ ratio 0.36 , while the $\mathrm{O} / \mathrm{C}$ for DEGDME is 0.5 . These results indicate that the experimental conditions (i.e. high power low amount of precursor flow and low pressure) used for the plasma processes contributed to a certain fragmentation of the precursor during the discharge and a certain ion bombardment of the organic deposited film during the process that produces a high cross linking of the deposited film (i.e. high hydrocarbon content). In the case of the $\mathrm{Ag}$ :CxHyOz coating the $\mathrm{O} / \mathrm{C}$ ratio was 0.29 and the percentage of $\mathrm{Ag}$ into the nacocomposite reached almost $20 \%$.

To assess if the organic matrix is the same with or without the presence of $\mathrm{Ag}$ clusters, an overlapping of high resolution XPS C1s spectra is reported in Figure 2(b). It is possible to see that the $\mathrm{C} 1 \mathrm{~s}$ spectra are almost identical confirming that the presence of $\mathrm{Ag}$ did not change the chemical characteristics of the organic layer and that the coating $\mathrm{CxHyOz}$ can be used as reference of $\mathrm{Ag}: \mathrm{CxHyOz}$ ones during antibacterial tests to disentangle the effect of the organic matrix to that one of silver.

\subsection{Water Contact Angle Measurements}

The hydrophilic character of plasma deposited coatings dramatically changed when $\mathrm{Ag}$ was introduced. As shown in Table 1 the presence of Ag clusters in the coating increased the advancing water contact angle $\left(\theta_{\text {adv }}\right)$ from $68 \pm 3^{\circ}$ in the case of the $\mathrm{CxHyOz}$ coating to $104 \pm$ $7^{\circ}$ in the case of the $\mathrm{Ag}: \mathrm{CxHyOz}$ one. Contemporary a very evident decrease of receding water contact angle $\left(\theta_{\text {rec}}\right.$, Table 1) was observed for the Ag:CxHyOz sam- ples. These findings show that a very important hysteresis was associated to the presence of Ag clusters. Hysteresis is defined as the difference between the maximum and the minimum WCA values measured in a dynamic mode onto a surface, i.e. the maximum angle while the droplet is increasing its volume $\left(\theta_{\text {adv }}\right)$ and the minimum just be fore the reduction of the contact area with the solid during the volume decreasing $\left(\theta_{\mathrm{rec}}\right)$. The hysteresis is originated by the presence of heterogeneities (in topography and/or chemical composition) which induce fluctuations in surface tension [32]. Since hysteresis originates from defects, the high hysteresis registered on $\mathrm{Ag}: \mathrm{CxHyOz}$ samples can be attributed to certain surface roughness other than chemical heterogeneity.

\subsection{Atomic Force Microscopy (AFM)}

Atomic Force Microscopy (AFM) was employed to investigate the morphology of the $\mathrm{Ag}: \mathrm{CxHyOz}$ samples and further explore the hysteresis observed in the WCA measurements. Figure 3 reports the comparison of the topography of the $\mathrm{CxHyOz}$ coating with that of the $\mathrm{Ag}: \mathrm{CxHyOz}$ one. The image shows that the $\mathrm{CxHyOz}$ coating appeared quite smooth with aroot mean square (RMS) roughness value of $0.2 \pm 0.1 \mathrm{~nm}$. Implementation of $\mathrm{Ag}$ into the organic coating significantly changed the morphology of the coating. Indeed, the RMS value increased up to ca. $7.43 \pm 0.37 \mathrm{~nm}$ and the surface was characterized by a dense and highly interconnected network of round-shape features having a mean height of $71.3 \pm 4.5 \mathrm{~nm}$ accounted for by $\mathrm{Ag}$ clusters.

Table 1. XPS chemical composition of the plasma deposited coatings and results of water contact angle measurements.

\begin{tabular}{ccccccc}
\hline Samples & $\mathbf{\% C}$ & $\mathbf{\% O}$ & $\mathbf{\% A g}$ & $\boldsymbol{\theta}_{\text {adv }}\left({ }^{\circ}\right)$ & $\boldsymbol{\theta}_{\text {rec }}\left({ }^{\circ}\right)$ & $\boldsymbol{\theta}_{\text {stat }}\left({ }^{\circ}\right)$ \\
\hline $\mathbf{C x H y O z}$ & 66.1 & 24.0 & --- & $68 \pm 3$ & $52 \pm 3$ & $61 \pm 1$ \\
Ag:CxHyOz & 62.4 & 17.9 & 19.7 & $104 \pm 7$ & $2 \pm 7$ & $108 \pm 2$ \\
\hline
\end{tabular}

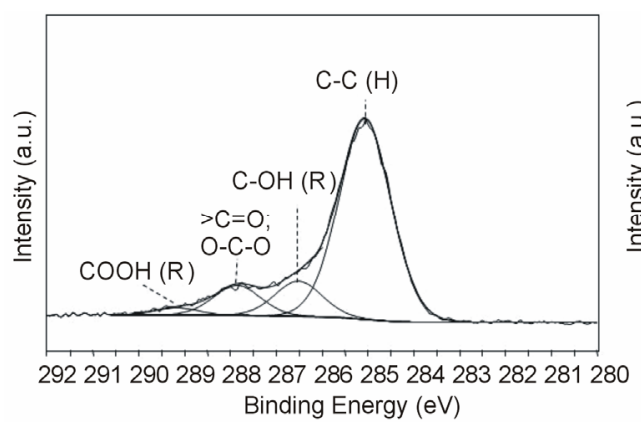

(a)

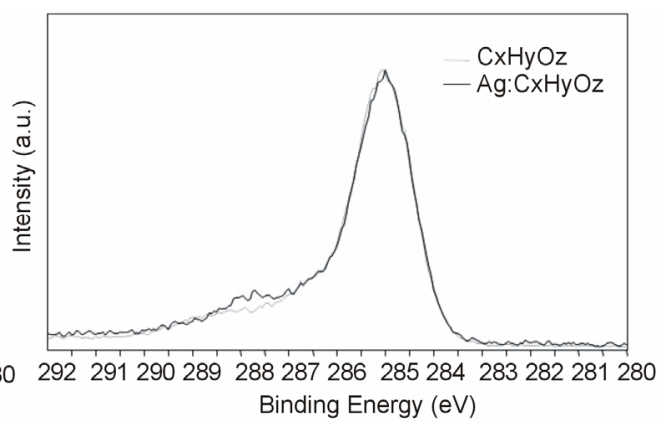

(b)

Figure 2. (a) XPS C1s spectrum acquired on $\mathrm{Ag}: \mathrm{CxHyOz}$ sample and best fitted in four components centred at $285.0 \pm 0.2 \mathrm{eV}$ (alkyl, C-C; C-H), $286.5 \pm 0.2 \mathrm{eV}$ (hydroxyl/ether, C-OH/COR), $287.8 \pm 0.2 \mathrm{eV}$ (carbonyl/aldehyde or Hemiacetal/Hemiketal, $>\mathrm{C}=\mathrm{O} / \mathrm{O}-\mathrm{C}-\mathrm{O}$ ), $289.2 \pm 0.2 \mathrm{eV}$ (carboxyl/ester, $\mathrm{COOH} / \mathrm{COOR}$ ); (b) overlapping of $\mathrm{C} 1 \mathrm{~s}$ spectra acquired on $\mathrm{CxHyOz}$ and Ag:CxHyOz samples. 


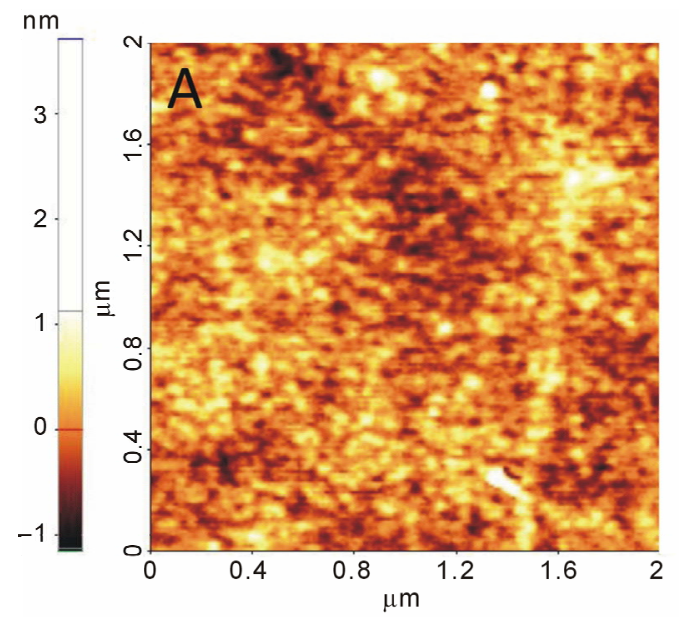

(a)

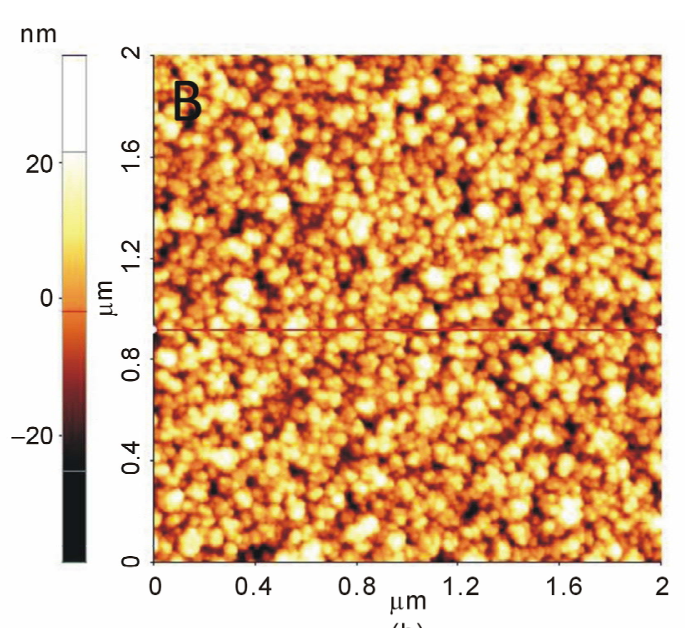

(b)

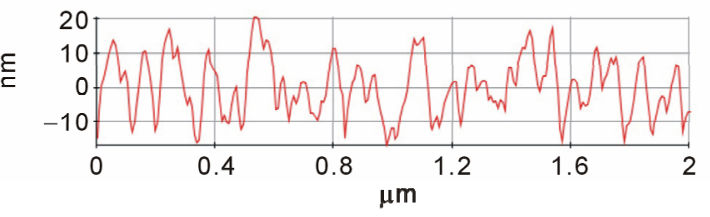

(c)

Figure 3. 2DAFM topography images of bare a) $\mathrm{CxHyOz}$ and b) $\mathrm{Ag}: \mathrm{CxHyOz}$ films. In panel c) cross sectional line profile taken along the red line of panel $B$.

\subsection{Silver Release}

ICP-MS characterization of plasma modified materials show a release of silver of $200 \pm 20 \mathrm{ppm} / \mathrm{cm}^{2}$ in the first 24 hrs.

\section{Bacterial Adhesion and Biofilm Formation}

\subsection{Colony Forming Units Counting Method}

Figure 4 shows the combined effect of surface chemistry and shear rate on bacterial adhesion (number of adherent bacteria $/ \mathrm{cm}^{2}$ ), as this was quantified by the Colony Forming Unit (CFU) method. Bacteria adhered significantly more to the $\mathrm{CxHyOz}$ coated PET in comparison to the Ag: $\mathrm{CxHyOz}$ coated one $(\mathrm{p}<0.01)$. A decrease in the number of adherent bacteria, for both materials, was observed when the shear rate increased from $50 \mathrm{~s}^{-1}$ to 2000 $\mathrm{s}^{-1}$. This decrease was significantly different $(\mathrm{p}<0.01)$, for all possible combinations. The lowest number of attached bacteria was calculated under the higher shear rate onto the Ag:CxHyOz coated PET.

\subsection{Scanning Electron Microscopy}

The SEM images revealed that, although the $\mathrm{CxHyOz}$ coated PET yielded the highest number of adherent bacteria, no slime production was observed while the bacteria were attached in a monolayer (Figure 5(a)). In the case of the Ag:CxHyOz coated PET the number of adherent bacteria was much lower than in the case of the

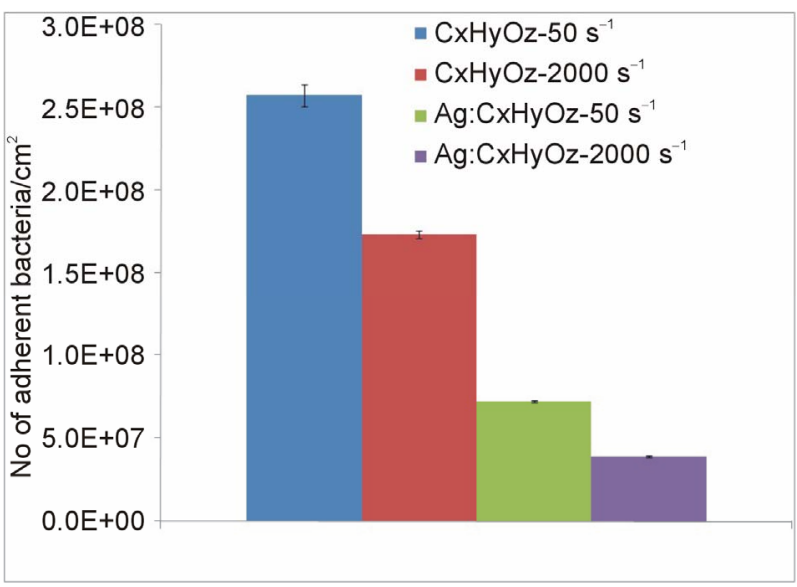

Figure 4. Mean values and standard deviation $(n=3)$ of the number of adherent bacteria/ $/ \mathrm{cm}^{2}(N)$ onto the $\mathrm{CxHyOz}$ and Ag: $\mathrm{CxHyOz}$ coated PET, two hours post adhesion, under shear rate of $50 \mathrm{~s}^{-1}$ and $2000 \mathrm{~s}^{-1} \cdot \mathrm{p}<0.001$ for all the possible combinations.

CxHyOz coated PET, for both shear rates, however apart from isolated bacteria, small aggregates and in some cases a second layer of adherent bacteria could be observed two hours after adhesion (Figure 5(b)), under both shear rates. The percentage of surface coverage by bacteria is summarised in Table 2.

\section{3. icaA Gene Expression}

Under all the tested conditions, icaA was mostly expressed 

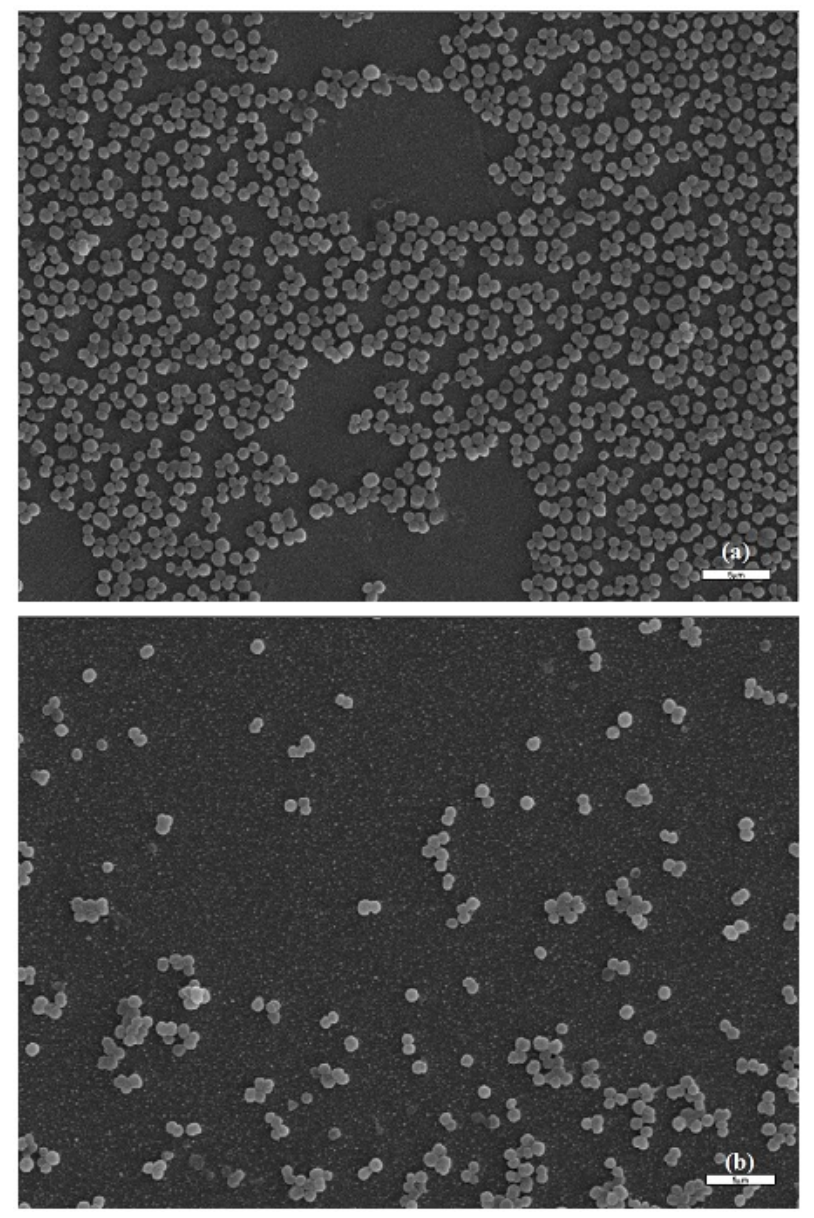

Figure 5. SEM images of bacteria interacting with the $\mathrm{CxHyOz}$ coated substrate (a) and the $\mathrm{Ag}: \mathrm{CxHyOz}$ coated substrate (b)under $50 \mathrm{~s}^{-1}$.

Table 2. Mean values and standard deviation $(n=3)$ of $\%$ surface coverage of the surface by bacteria, as this was quantified using SEM and image analysis.

\begin{tabular}{|c|c|}
\hline Samples & $\%$ Surface Coverage \\
\hline CxHyOz, $50 \mathrm{~s}^{-1}$ & $72.7 \pm 2.5$ \\
\hline CxHyOz, 2000 s $^{-1}$ & $55.9 \pm 3.1$ \\
\hline Ag:CxHyOz, 50 s $^{-1}$ & $21.3 \pm 1.9$ \\
\hline Ag:CxHyOz, $2000 \mathrm{~s}^{-1}$ & $16.5 \pm 2.3$ \\
\hline
\end{tabular}

by the adherent than the planktonic bacteria (Figure 6) (p $<0.001$ ), showing its implication to biofilm formation by the adherent bacteria.

$i c a A$ expression was always statistically significantly higher for bacteria interacting with the $\mathrm{Ag}: \mathrm{CxHyOz}$ coated PET, both adherent and planktonic, than for those on the $\mathrm{CxHyOz}$ coating $(\mathrm{p}<0.001)$ (Figure 6). Furthermore, the increase in shear rate statistically significantly enhanced the expression of $i c a A$ gene for both adherent and planktonic bacteria, interacting with both $\mathrm{CxHyOz}$ and $\mathrm{Ag}: \mathrm{CxHyOz}$ coated PET $(\mathrm{p}<0.001)$ (Figure 6).

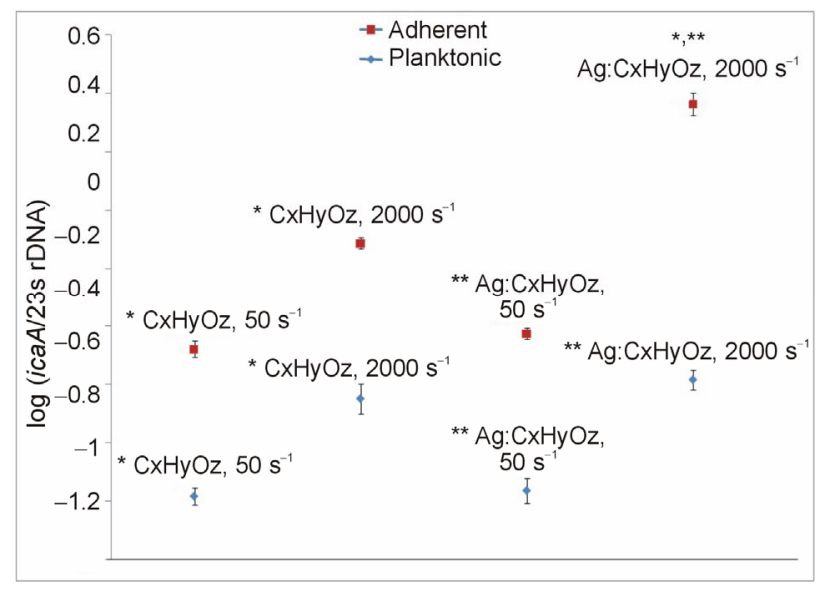

Figure 6. Effect of shear rate and surface chemistry on adherent and planktonic bacterial ica $A$ gene expression, two hours post adhesion. Results are expressed as mean values and error bars indicate standard deviation $(n=3)$. ${ }^{*}$ and ${ }^{* *} p$ $<0.001$, when the results for either the adherent or the planktonic bacteria are compared.

\section{Discussion}

In this study the contributions of $\mathrm{Ag}$ and shear rate on $S$. epidermidis adhesion, accumulation and icaA expression were investigated through the plasma deposition of nanocomposite coatings with and without $20 \% \mathrm{Ag}$; Ag:CxHyOz and $\mathrm{CxHyOz}$ respectively. The relative contribution of physicochemical and hydrodynamic interactions on bacterial adhesion and specific gene expression was addressed by quantitative measurement of bacterial adhesion and gene expression on $\mathrm{CxHyOz}$ and $\mathrm{Ag}: \mathrm{CxHyOz}$ coated PET in laminar flow, as a function of fluid shear rate.

The CFUs counting method showed that S. epidermidis adhered significantly more to the $\mathrm{CxHyOz}$ coating in comparison to the $\mathrm{Ag}$ : $\mathrm{CxHyO}$ zone $(\mathrm{p}<0.01)$, and this is in agreementwith our previous study [33] that showed decreased bacterial adhesion to the Ag plasma coated poly (vinyl chloride) (PVC), in comparison to the untreated PVC. In parallel, it was observed that the increase in shear rate significantly reduced bacterial adhesion to both materials. However, almost $30 \%$ of the attached to the $\mathrm{Ag}: \mathrm{CxHyOz}$ coating bacteria, in comparison to the $\mathrm{CxHyOz}$, remained alive and although the number of adherent bacteria was significantly lower than in the case of the $\mathrm{CxHyOz}$ coated PET, apart from isolated bacteria, small aggregates and in some cases a second layer of adherent bacteria could be observed on the $\mathrm{Ag}: \mathrm{CxHyOz}$ coated PET, under both shear rates.

Although Chaw et al., [22] and Qu et al., [34] AFM studies showed that Ag ions interfere with bacteria-bacteria and bacteria-material interactions, through the binding of Ag ions to electron donor groups of the biological 
molecules, leading to reductions in the number of binding sites for hydrogen bonds and electrostatic and hydrophobic interactions and, hence, the destabilization of the biofilm structure [22,34], Qu et al., showed that far fewer $S$. aureus and $S$. marcescens than $P$. aeruginosa were actually killed by the Ag ions release and this was attributed to the differences in the cell wall [34]. Specifically, the cell walls of Gram-positive species contain 3 - 20 times more peptidoglycan than Gram-negative bacteria [35], and probably bind some portion of the $\mathrm{Ag}$ ions. Consequently, Gram-positive bacteria are generally less susceptible to antibacterial agents containing $\mathrm{Ag}$ than Gram-negative species [35]. This is in agreement with Sandström observation that when a staphylococcal suspension of $10^{8}-10^{9} \mathrm{CFU} / \mathrm{ml}$ was used, the minimum bactericidal concentration of Ag was found to be above $987 \mathrm{ppm}$ [36]. This could explain our present results that showed that almost $30 \%$ of the attached to the Ag: $\mathrm{CxHyOz}$ coating bacteria, in comparison to the $\mathrm{CxHyOz}$ coating, were alive, 2 hours after adhesion and while $100 \mathrm{ppm}$ of $\mathrm{Ag}$ had been released.

In order to investigate possible links between phenotypic responses and genetic activity of bacteria during bacteria-material interactions under shear conditions, assessment of $i \mathrm{caA}$ gene expression towards a part of $23 \mathrm{~S}$ rDNA was performed, for both planktonic and adherent bacteria. icaA expression seems to be influenced by both the material surface chemistry and the shear conditions mainly for the adherent bacteria at early adhesion stages. In particular, it was observed that icaA expression level was always higher for the adherent bacteria in comparison to the planktonic, showing its implication to biofilm formation by the adherent bacteria and not that much by those that are in suspension.

In addition, the results showed that icaA gene expression was influenced by the surface chemistry as well, mainly for the adherent bacteria. In particular, higher expression of $i c a A$ gene was observed for the bacteria that were interacting with the $\mathrm{Ag}: \mathrm{CxHyOz}$ coating than with the $\mathrm{CxHyOz}$ one, for all the tested conditions. This possibly means that although the $\mathrm{Ag}: \mathrm{CxHyOz}$ coating reduced bacterial adhesion, in comparison to the $\mathrm{CxHyOz}$ one, the amount of $\mathrm{Ag}$ that was released and did not kill all the adherent bacteria caused increased expression of ica $A$ gene. In the case of the planktonic bacteria, the ica $A$ gene expression was not as much influenced by the material surface chemistry, as in the case of adherent bacteria.

Apart from the stress caused to bacteria by the subbactericidal concentration of $\mathrm{Ag}$ and resulted in enhanced icaA gene expression, the increase in shear rate significantly increased the expression levels of icaA as well, for both $\mathrm{CxHyOz}$ and $\mathrm{Ag}: \mathrm{CxHyOz}$ coatings and for both adherent and planktonic bacteria, meaning that the sur- face chemistry in combination with the shear conditions affect the phenotypic responses of bacteria to bacteria-material and result in gene expression profile alterations.

Trying to compare these results with other in the literature, there are some studies that have also identified genes that were differentially expressed in biofilm and planktonic populations. In particular, Prigent-Combaret et al., reported that the colonic acid exopollysaccharide (wca locus) was expressed in higher levels by adherent $E$. coli bacteria than by the planktonic, whereas the flagellin $(f l i C)$ gene expression was reduced in biofilms [37]. Furthermore, Becker et al., identified five genes which were differentially expressed in biofilm and planktonic populations of S. aureus [38], while early high transcription of icaA has been also reported in a study using stainless steel [39] and during an in vitro foreign-body colonization model [40]. Concerning the effect of substances' sub-bactericidal concentrations on gene expression Fitzpatrick et al., have also shown that the number of icapositive biofilm-positive bacteria under stress-inducing growth conditions, and in particular in the presence of $\mathrm{NaCl}$, ethanol or subinhibitory tetracycline concentrations, increased significantly from $15.3 \%$ to $73 \%$, in comparison to the standard growth conditions [41]. Moreover, Kuehl et al., observed biofilm enhancement by furanone in staphylococci at subinhibitory concentrations, which was correlated with an increase in PIA synthesis and dependent on $\operatorname{luxS}$ gene expression, although the mechanism of interaction between luxS and PIA under furanone treatment remained unclear [42]. In another study though, the level of biomaterial-induced icaA expression could not be correlated with the material physicochemical properties or the amount of biofilm formed, but with the ability of bacteria in surviving antibiotic attack [43]. These results therefore showed that there was an increase in biofilm formation when bacteria were under stress due to various environmental factors. Alterations of these factors can ultimately give an insight of how bacteria-material interactions are influenced by their surroundings.

In our previous study it was also observed that bacterial adhesion as well as slime production and biofilm formation were influenced by the surface chemistry [27]. In particular, much higher biofilm formation was observed on the hydrophobic $\mathrm{CH}_{3}$-teminated glass than on the hydrophilic $\mathrm{OH}$-terminated one, for three S. epidermidis strains, and this was in agreement with icaA and $i c a D$ increased gene expression for the bacteria adhering to the $\mathrm{CH}_{3}$-terminated substrate. The decreased surface energy of the $\mathrm{Ag}: \mathrm{CxHyOz}$ coating, in comparison to the $\mathrm{CxHyOz}$, could be therefore another reason for the increased icaA gene expression in the case of the 
$\mathrm{Ag}: \mathrm{CxHyOz}$ coating two hours post adhesion. Furthermore both this study and the previous one [27] showed that the flow conditions and the associated hydrodynamic forces strongly influence not only the number of attached bacteria, but genes functionality related to biofilm formation as well.

In the same directions, Thomas et al., observed that shear stress strengthened E. coli attachment to red blood cells through biological interactions that were enhanced by mechanical force pulling a ligand-receptor complex apart, and are known as "catch bonds" [44]. Moreover, Weaver et al., showed that fluid flow induced biofilm formation in S. epidermidis PIA-positive clinical isolates [45].

These findings suggest that bacteria are able to sense and respond to surfaces and environmental signals using mechanisms that remain poorly understood and that the regulation of biofilm formation under altered growth conditions, which may exist in the in vivo environment, also plays a possible role in the pathogenesis of biomaterial-related S. epidermidis infections.

The results of the present study therefore suggest that although the incorporation of $\mathrm{Ag}$ in $\mathrm{CxHyOz}$ as a biomaterial coating can decrease bacterial adhesion and viability, in comparison to the $\mathrm{CxHyOz}$ alone, its presence at sub-bactericidal concentrations, especially when Grampositive bacteria are implicated, and its application at high shear rate environments such as aortic grafts and catheters, can significantly increase ica $A$ gene expression and therefore the risk of biofilm formation. In this direction, the effect of shear stress on alterations in genes expression of adhering bacteria is another parameter that should be taken into consideration for the design of biomaterials, and the biomaterial coating strategies should be evaluated and applied after considering important details unique or specific to each application. This could probably mean that $\mathrm{Ag}$ release should be quicker for biomaterials that are inserted in high shear environments and when Gram-positive bacteria are implicated. Furthermore, for applications that tissue integration is desirablethe use of medical devices containing Ag must be undertaken with caution, since a concentration-dependent toxicity has been demonstrated [46].

A limitation of the present study is that the reactivity of other genes contributing to $S$. epidermidis adhesion and biofilm formation under the same conditions has not been tested.

\section{Conclusion}

This study was conducted utilizing two shear rates and two surface functionalities, in order to investigate how the combination of antimicrobial properties, through plasma deposition of $\mathrm{Ag}$ containing nanocomposite coat- ing, and hydrodynamic conditions influence bacterial viability, adhesion and icaA gene expression. The results showed that both the surface chemistry and the shear conditions parameters significantly influenced $S$. epidermidis adhesion and the expression of ica locus. The combination of both conventional phenotypic analysis, using the CFU method and SEM, and genotypic analysis, using the relative reverse transcription polymerase chain reaction (RT-PCR), offered the potential to explore the links between phenotypic responses to bacteria-material interactions and gene expression profile alterations, under dynamic conditions. Bacterial adhesion was much higher on the $\mathrm{CxHyOz}$ coated PET than on the $\mathrm{Ag}: \mathrm{CxHyOz}$ coated one. However, the $\mathrm{Ag}$ release at sub-bactericidal concentrations in combination with the increase in shear rate significantly enhanced icaA gene expression for the bacteria that were attached to the $\mathrm{Ag}: \mathrm{CxHyOz}$ coating. These observations indicate therefore that a quicker Ag release could possibly prevent bacterial adhesion and icaA gene expression, while the analysis of gene expression, along with the use of appropriate microscopies seems to be able to provide a more comprehensive and integrated insight into the bacterialmaterial interactions, and also introduce novel bioassays towards biomaterials antimicrobial assessment.

\section{Acknowledgements}

This project was partially funded by the programme: INTERREG IIIA: GREECE-ITALY "Establishment of a Multidisciplinary Scientific Network for the development and application of Advanced Biomaterials" 20062008 and by the funding of the National Staphylococcal Reference Laboratory, Greece, under the scientific responsibility of I. S. (grant C954, KEELPNO).

\section{REFERENCES}

[1] R. Y. Kannan, H. J. Salacinski, P. E. Butler, G. Hamilton and A. M. Seifalian, "Current Status of Prosthetic Bypass Grafts: A Review," Journal of Biomedical Materials Research Part B: Applied Biomaterials, Vol. 74B, No. 1, 2005, pp. 570-581.

http://dx.doi.org/10.1002/jbm.b.30247

[2] C. Von Eiff, G. Peters and C. Heilmann, "Pathogenesis of Infections Due to Coagulase-Negative Staphylococci," The Lancet Infectious Diseases, Vol. 2, No. 11, 2002, pp. 677-685.

http://dx.doi.org/10.1016/S1473-3099(02)00438-3

[3] J.-L. Vincent, "Nosocomial Infections in Adult IntensiveCare Units," Lancet, Vol. 361, No. 9374, 2003, pp. 20682077. http://dx.doi.org/10.1016/S0140-6736(03)13644-6

[4] C. Vuong and M. Otto, "Staphylococcus epidermidis Infections," Microbes and Infection, Vol. 4, No. 4, 2002, pp. 481-489. 
http://dx.doi.org/10.1016/S1286-4579(02)01563-0

[5] J. W. Costerton, P. S. Stewart and E. P. Greenberg, "Bacterial Biofilms: A Common Cause of Persistent Infections," Science, Vol. 284, No. 5418, 1999, pp. 1318-1322. http://dx.doi.org/10.1126/science.284.5418.1318

[6] R. M. Donlan and J. W. Costerton, "Biofilms: Survival Mechanisms of Clinically Relevant Microorganisms," Clinical Microbiology Reviews, Vol. 15, No. 2, 2002, pp. 167-193.

http://dx.doi.org/10.1128/CMR.15.2.167-193.2002

[7] C. Heilmann, O. Schweitzer, C. Gerke, N. Vanittanakom, D. Mack and F. Gotz, "Molecular Basis of Intercellular Adhesion in the Biofilm-Forming Staphylococcus epidermidis," Molecular Microbiology, Vol. 20, No. 5, 1996, pp. 1083-1091. http://dx.doi.org/10.1111/j.1365-2958.1996.tb02548.x

[8] H. Rohde, S. Frankenberger, U. Zähringer and D. Mack, "Structure, Function and Contribution of Polysaccharide Intercellular Adhesin (PIA) to Staphylococcus epidermidis Biofilm Formation and Pathogenesis of Biomaterial-Associated Infections," European Journal of Cell Biology, Vol. 89, No. 1, 2010, pp. 103-111. http://dx.doi.org/10.1016/j.ejcb.2009.10.005

[9] G. B. Perera, R. M. Fujitani and S. M. Kubaska, "Aortic Graft Infection: Update on Management and Treatment Options," Vascular and Endovascular Surgery, Vol. 40, No. 1, 2006, pp. 1-10. http://dx.doi.org/10.1177/153857440604000101

[10] S. Jamel, R. Attia and C. Young, "Management of an Infected Aortic Graft with Endovascular Stent Grafting," Diagnostic and Interventional Radiology, Vol. 19, No. 1, 2013, pp. 66-69.

[11] A. T. Ali, J. G. Modrall, J. Hocking, R. J. Valentine, H. Spencer, J. F. Eidt and G. P. Clagett, "Long Term Results of the Treatment of Aortic Graft Infection by in Situ Replacement with Femoral Popliteal Vein Grafts," Journal of Vascular Surgery, Vol. 50, No. 1, 2009, pp. 30-39. http://dx.doi.org/10.1016/j.jvs.2009.01.008

[12] P. F. Lawrence, "Conservative Treatment of Aortic Graft Infection," Seminars in Vascular Surgery, Vol. 24, No. 4, 2011, pp. 199-204.

http://dx.doi.org/10.1053/j.semvascsurg.2011.10.014

[13] D. Campoccia, L. Montanaro, P. Spezialec and C. R. Arciola, "Antibiotic-Loaded Biomaterials and the Risks for the Spread of Antibiotic Resistance Following Their Prophylactic and Therapeutic Clinical Use," Biomaterials, Vol. 31, No. 25, 2010, pp. 6363-6377. http://dx.doi.org/10.1016/j.biomaterials.2010.05.005

[14] D. J. Balazs, K. Triandafillu, E. Sardella, G. Iacoviello, P. Favia, R. d'Agostino, H. Harms and H. J. Mathieu, "PE-CVD Modification of Medical Grade PVC to Inhibit Bacterial Adhesion: PEO-Like and Nano-Composite Ag/PEO-Like Coatings," In: R. d'Agostino, P. Favia, M. R. Wertheimer and C. Oehr, Eds., Plasma Processes and Polymers, Wiley-VCH Verlag GmbH \& Co. KGaA, Weinheim, 2005, pp. 351-372. http://dx.doi.org/10.1002/3527605584.ch26

[15] F. Furno, K. S. Morley, B. Wong, B. L. Sharp, P. L. Ar- nold, S. M. Howdle, R. Bayston, P. D. Brown, P. D Winship and H. J. Reid, "Silver Nanoparticles and Polymeric Medical Devices: A New Approach to Prevention of Infection?" Journal of Antimicrobial Chemotherapy, Vol. 54, No. 6, 2004, pp. 1019-1024. http://dx.doi.org/10.1093/jac/dkh478

[16] N. Stobie, B. Duffy, D. E. McCormack, J. Colreavy, M. Hidalgo, P. McHale and S. Hinder, "Prevention of Staphylococcus epidermidis Biofilm Formation Using a Low-Temperature Processed Silver-Doped Phenyltriethoxysilane Sol-Gel Coating," Biomaterials, Vol. 29, No. 8, 2008, pp. 963-969. http://dx.doi.org/10.1016/j.biomaterials.2007.10.057

[17] E. M. Hetrick and M. H. Schoenfisch, "Reducing Implant-Related Infections: Active Release Strategies," Chemical Society Reviews, Vol. 35, No. 9, 2006, pp. 780-789. http://dx.doi.org/10.1039/b515219b

[18] N. Cerca, G. B. Pier, M. Vilanova, R. Oliveira and J. Azeredo, "Quantitative Analysis of Adhesion and Biofilm Formation on Hydrophilic and Hydrophobic Surfaces of Clinical Isolates of Staphylococcus epidermidis," Research in Microbiology, Vol. 156, No. 4, 2005, pp. 506514. http://dx.doi.org/10.1016/j.resmic.2005.01.007

[19] S. Kajiyama, T. Tsurumoto, M. Osaki, K. Yanagihara and H. Shindo, "Quantitative Analysis of Staphylococcus epidermidis Biofilm on the Surface of Biomaterial," Journal of Orthopaedic Science, Vol. 14, No. 6, 2009, pp. 769775. http://dx.doi.org/10.1007/s00776-009-1405-0

[20] M. W. Pfaffl, "Quantification Strategies in Real-Time PCR," In: S. A. Bustin, Ed., A-Z of Quantitative PCR, International University Line (IUL), La Jolla, 2004, pp. 89-113.

[21] M. Otto, "Molecular Basis of Staphylococcus epidermidis infections," Seminars in Immunopathology, Vol. 34, No. 2, 2012, pp. 201-214. http://dx.doi.org/10.1007/s00281-011-0296-2

[22] K. C. Chaw, M. Manimaran and E. H. Tay Francis, "Role of Silver Ions in Destabilization of Intermolecular Adhesion Forces Measured by Atomic Force Microscopy in Staphylococcus epidermidis Biofilms," Antimicrobial Agents and Chemotherapy, Vol. 49, No. 12, 2005, pp. 4853-4859.

http://dx.doi.org/10.1128/AAC.49.12.4853-4859.2005

[23] H. L. Goldsmith and V. T. Turitto, "Reological Aspects of Thrombosis and Haemostasis: Basic Principles and Applications," Thrombosis and Haemostasis, Vol. 55, No. 3, 1986, pp. 415-435.

[24] P. Favia, M. Vulpio, R. Marino, R. d'Agostino, R. P. Mota and M. Catalano, "Plasma-Deposition of Ag-Containing Polyethyleneoxide-Like Coatings," Plasmas and Polymers, Vol. 5, No. 1, 2000, pp. 1-14. http://dx.doi.org/10.1023/A:1009517408368

[25] P. Favia, M. Creatore, F. Palumbo, V. Colaprico and R. d'Agostino, "Process Control for Plasma Processing of Polymers," Surface and Coatings Technology, Vol. 142144, 2001, pp. 1-6. http://dx.doi.org/10.1016/S0257-8972(01)01191-4

[26] G. Beamson and D. Briggs, "High Resolution XPS of 
Organic Polymers: The Scienta ESCA300 Database," Wiley, Chichester, 1992.

[27] A. Foka, M. G. Katsikogianni, E. D. Anastassiou, I. Spiliopoulou and Y. F. Missirlis, "The Combined Effect of Surface Chemistry and Flow Conditions on Staphylococcus epidermidis Adhesion and Ica Operon Expression," European Cells Mater, Vol. 24, 2012, pp. 386-402.

[28] M. Stavridi, M. Katsikogianni and Y. F. Missirlis, "The Influence of Surface Patterning and/or Sterilization on the Haemocompatibility of Polycaprolactones," Materials Science and Engineering: C, Vol. 23, No. 3, 2003, pp. 359-365.

http://dx.doi.org/10.1016/S0928-4931(02)00287-4

[29] C. R. Arciola, D. Campoccia, M. Cervellati, E. Donati and L. Montanaro, "Detection of Slime Production by Means of an Optimised Congo Red Agar Plate Test Based on a Colourimetric Scale in Staphylococcus epidermidis Clinical Isolates Genotyped for Ica Locus," Biomaterials, Vol. 23, No. 21, 2002, pp. 4233-4239.

http://dx.doi.org/10.1016/S0142-9612(02)00171-0

[30] V. Chini, A. Foka, G. Dimitracopoulos and I. Spiliopoulou, "Absolute and Relative Real-Time PCR in the Quantification of tst Gene Expression among Methicillin-Resistant Staphylococcus aureus: Evaluation by Two Mathematical Models," Letters in Applied Microbiology, Vol. 45, No. 5, 2007, pp. 479-484.

http://dx.doi.org/10.1111/j.1472-765X.2007.02208.x

[31] U. Fluckiger, M. Ultrich, A. Steinhuber, G. Döring, D. Mack, R. Landmann, C. Goerke and C. Woltz, "Biofilm Formation, icaADBC Transcription and Polysaccharide Intercellular Adhesin Synthesis by Staphylococci in a Device-Related Infection Model," Infection and Immunity, Vol. 73, No. 3, 2005, pp. 1811-1819. http://dx.doi.org/10.1128/IAI.73.3.1811-1819.2005

[32] P. G. De Gennes, "Wetting: Static and Dynamic," Reviews of Modern Physics, Vol. 57, No. 3, 1985, pp. 827864. http://dx.doi.org/10.1103/RevModPhys.57.827

[33] M. Katsikogianni, I. Spiliopoulou, D. P. Dowling and Y. F. Missirlis, "Adhesion of Slime Producing Staphylococcus epidermidis Strains to PVC and Diamond-Like Carbon/Silver/Fluorinated Coatings," Journal of Materials Science: Materials in Medicine, Vol. 17, No. 8, 2006, pp. 679-689. http://dx.doi.org/10.1007/s10856-006-9678-8

[34] W. Qu, H. J. Busscher, H. C. van der Mei and J. M. M. Hooymans, "Bacterial Adhesion Forces to Ag-Impregnated Contact Lens Cases and Transmission to Contact Lenses," Cornea, Vol. 32, No. 3, 2013, pp. 326-331. http://dx.doi.org/10.1097/ICO.0b013e31825837ea

[35] K. Kawahara, K. Tsuruda, M. Morishita and M. Uchida, "Antibacterial Effect of Silver-Zeolite on Oral Bacteria under Anaerobic Conditions," Dental Materials, Vol. 16, No. 6, 2000, pp. 452-455. http://dx.doi.org/10.1016/S0109-5641(00)00050-6

[36] S. Sandström, "The Antibacterial Effect of Silver with Different Release Kinetics," Ph.D. Dissertation, Chalmers University of Technology, Goteborg, 2011.

http://publications.lib.chalmers.se/records/fulltext/141686 .pdf

[37] C. Prigent-Combaret, O. Vidal, C. Dorel and P. Lejeune, "Abiotic Surface Sensing and Biofilm-Dependent Regulation of Gene Expression in Escherichia coli," Journal of Bacteriology, Vol. 181, No. 19, 1999, pp. 5993-6002.

[38] P. Becker, W. Hufnagle, G. Peters and M. Herrmann, "Detection of Different Gene Expression in BiofilmForming versus Planktonic Populations of Staphylococcus aureus Using Micro-Representational-Difference Analysis," Applied and Environmental Microbiology, Vol. 67, No. 7, 2001, pp. 2958-2965. http://dx.doi.org/10.1128/AEM.67.7.2958-2965.2001

[39] S. Kajiyama, T. Tsurumoto, M. Osaki, K. Yanagihara and H. Shindo, "Quantitative analysis of Staphylococcus epidermidis Biofilm on the Surface of Biomaterial," Journal of Orthopaedic Science, Vol. 14, No. 6, 2009, pp. 769775. http://dx.doi.org/10.1007/s00776-009-1405-0

[40] S. J. Vandecasteele, W. E. Peetermans, A. Carbonez and J. Van Eldere, "Metabolic Activity of Staphylococcus epidermidis Is High during Initial and Low during Late Experimental Foreign-Body Infection," Journal of Bacteriology, Vol. 186, No. 8, 2004, pp. 2236-2239. http://dx.doi.org/10.1128/JB.186.8.2236-2239.2004

[41] F. Fitzpatrick, H. Humphreys, E. Smythy, C. A. Kennedy and J. P. O'Gara, "Environmental Regulation of Biofilm Formation in Intensive Care Unit Isolates of Staphylococcus epidermidis," Journal of Hospital Infection, Vol. 52, No. 3, 2002, pp. 212-218.

http://dx.doi.org/10.1053/jhin.2002.1309

[42] R. Kuehl, S. Al-Bataineh, O. Gordon, R. Luginbuehl, M. Otto, M. Textor and R. Landmann, "Furanone at Subinhibitory Concentrations Enhances Staphylococcal Biofilm Formation by luxS Repression," Antimicrobial Agents and Chemotherapy, Vol. 53, No. 10, 2009, pp. 4159-4166. http://dx.doi.org/10.1128/AAC.01704-08

[43] T. Nuryastuti, B. P. Krom, A. T. Aman, H. J. Busscher and H. C. van der Mei, "Ica-Expression and Gentamicin Susceptibility of Staphylococcus epidermidis Biofilm on Orthopedic Implant Biomaterials," Journal of Biomedical Materials Research Part A, Vol. 96A, No. 2, 2011, pp. 365-371. http://dx.doi.org/10.1002/jbm.a.32984

[44] W. Thomas, E. Trintchina, M. Forero, V. Vogel and E. Sokurenko, "Bacterial Adhesion to Target Cells Enhanced by Shear Force," Cell, Vol. 109, No. 7, 2002, pp. 913-923. http://dx.doi.org/10.1016/S0092-8674(02)00796-1

[45] W. M. Weaver, V. Milisavljevic, J. F. Miller and D. Di Carlo, "Fluid Flow Induces Biofilm Formation in Staphylococcus epidermidis Polysaccharide Intracellular Adhesin-Positive Clinical Isolates," Applied and Environmental Microbiology, Vol. 78, No. 16, 2012, pp. 5890- 5896. http://dx.doi.org/10.1128/AEM.01139-12

[46] L. Braydich-Stolle, S. Hussain, J. J. Schlager and M. C. Hofmann, "In Vitro Cytotoxicity of Nanoparticles in Mammalian Germline Stem Cells," Toxicological Sciences, Vol. 88, No. 2, 2005, pp. 412-419. http://dx.doi.org/10.1093/toxsci/kfi256 